\title{
Reflections on Islamic Feminist Exegesis of the Qur'an
}

\author{
amina wadud ${ }^{1,2}$
}

\author{
1 Starr King School for the Ministry, Oakland, CA 94613, USA; awadud@sksm.edu \\ 2 Post-Graduate Program, National Islamic University Sunan Kalijaga, Yogyakarta 55281, Indonesia
}

Citation: wadud, amina. 2021. Reflections on Islamic Feminist Exegesis of the Qur'an. Religions 12: 497. https://doi.org/10.3390/ rel12070497

Academic Editors: Roberto Tottoli and Terry Lovat

Received: 19 May 2021

Accepted: 24 June 2021

Published: 3 July 2021

Publisher's Note: MDPI stays neutral with regard to jurisdictional claims in published maps and institutional affiliations.

Copyright: (C) 2021 by the author. Licensee MDPI, Basel, Switzerland. This article is an open access article distributed under the terms and conditions of the Creative Commons Attribution (CC BY) license (https:// creativecommons.org/licenses/by/ $4.0 /)$.

\begin{abstract}
The chapter highlights the importance of lived realities to the hermeneutics of the Qur'an and questions the classical interpretation of the Qur'an, evidencing that the dominant and prolific model of centering analysis of the sacred text and religious practices around men and men's experience. Discussing attitudes and specific Qur'an passages, neutral terminology in relation to creation and cosmology, the story of Lot/Lut, and themes such as the question of Shari'ah, the paper offers a personal reflection on gender and Qur'anic or Islamic interpretative possibilities. The author also explains how she came to a theological perspective on the equality of gender and gender identity over the last two decades, and gives specific examples of a unique Qur'anic analysis.
\end{abstract}

Keywords: qur'an; islam; qur'an exegesis; feminism; women; islamic feminism

\section{Introduction}

Islamic feminist exegesis of the Qur'an was a precursor to the rise of Islamic feminism as a methodology and movement. In 1992, when I published my PhD dissertation under the name Qur'an and Woman (Wadud 1992), there was no such thing as Islamic feminism. Instead, one had to choose between feminisms that were overwhelmingly hostile to religion - especially Islam - and the dominant interpretation of Islam that was overwhelmingly patriarchal. These are now referred to as secular feminism and Islamism or political Islam. The most common mantra was: you cannot have feminism and Islam. While some still think this is the case, overall a vibrant and intersectional movement began to develop as we entered the new millennium, challenging the dominant rubrics of both feminism and Islam.

The first publication of Qur'an and Woman, with Fajar Bakhti Press, an Oxford University Press subsidiary, in Malaysia, did not lead to a revolution. While it was being edited for publication, I entered a new revolutionary life trajectory that would impact my interpretive work. As one of eight founding members of a grassroots women's organization called Sisters in Islam, (SIS, https: / / sistersinislam.org, accessed on 22 June 2021) I would enter Muslim feminist activism for social justice from an Islamic faith perspective, which would change my textual hermeneutics. As a PhD student, it was easy to locate my individual self as a Muslim woman within my exegesis. I had no concept of relating it to Muslim women as a collective in their lived realities within the context of culture, policy and law. There is no Muslim personal status law in the US. The adhoc legal postulates in certain Muslim communities are overwhelmingly patriarchal, but these are not the law of the land and thus lack state enforcement. Working with SIS for the three years I was in Malaysia, I saw the important nexus between theory and praxis. This would lead me to promote the idea of context over text in my analysis.

The context of lived realities for Muslim women-especially when used in the codification of public policy-would come to eclipse the text wherever it was used to enforce patriarchal hegemony. In this chapter, I will discuss the importance of lived realities to the hermeneutics of the Qur'an. This led to new knowledge production (The Women's Stories, Women's Lives: Male Authority in Muslim Contexts (2016) www.musawah.org, ${ }^{1}$ accessed on 22 June 2021) and an expansion of authority beyond the dominant male control 
of nearly 14 centuries. In turn, this would lead me to Islamic feminism. As the Islamic feminist movement began to unfold in the 1990s, it challenged the existing frameworks of feminisms even amongst Muslims. It also helped me to transform my approach to hermeneutics. While Islamic feminism could be said to be part of global feminisms and of Islamic reform in the new millennium, it has taken a more comprehensive and truly global step than any other aspects of Islamic reform. Indeed, any aspect of reform that does not engage with gender dynamics is outdated and incomplete.

The journey towards Islamic feminist knowledge production-as distinct from previously confirmed ideas of feminism-depended upon a coherent methodology of using gender as a category of interrogation for all Islamic primary sources, and for their applications in law and culture. It dismantled more than a thousand years of patriarchal control over textual exegesis and Muslims' lives. While Islamic feminism centers on the lived realities of Muslim women, it is not just about women. It is about moving the understanding of gender from hegemony and control to equality and reciprocity.

My first book, Qur'an and Woman, is deeply intuitive, critically analytical and explicitly gender inclusive. It enhanced the field of Qur'anic exegesis not only by confirming that Muslim women speak, but also by providing evidence that when we speak we do so from our own realities. Furthermore, it gave evidence that men had been speaking from their own lived realities for centuries and calling it universal. As Muslim women speak, we say some things differently from that which men have said for over a millennium. Although Islamic feminist exegesis is more than just women, to include women's lived realities in Qur'anic analysis challenges the dominant and prolific model of centering analysis of the sacred text and religious practices around men and men's experience as if universal. By centering women's voices and experiences in the way the primary texts were understood and adjudicated, the whole rubric of patriarchal hegemony was upset. Islamic feminism takes into consideration the epistemology of textual analysis by constructing gender as a category of thought. This had never been a conscious part of feminist analysis and critique before the end of the 20th century. Instead, Muslim women and men who identified with feminism identified with the dominant imperialist feminism of the global north. For whatever merits these previously existing feminisms might offer, the potential for rejection amongst lay Muslims was forestalled when the methodology for gender reforms was drawn from Islamic sources without the patriarchal readings of the past.

In the past, classical Islamic intellectual traditions operated within a well entrenched patriarchal model, taking for granted that men were the ideal agents and that they were superior to women as a matter of cosmology, theology, epistemology and praxis. Men were in charge and women were here to support men's movement toward the divine. To be sure, classical Islamic thought expressed the general understanding, promoted in the Qur' an and by the Prophet(s), that women are fully human. Simultaneously, patriarchal interpretation subtracted from women's full humanity at almost every turn. Patriarchy is not the subject of my discussion here, but (as the elephant in the room) I will indicate how I understand it in order to show why it is not the focus. To focus on patriarchy distracts from the tasks I have taken up over a life time and once again centers the discussions around men; men's ways of knowing, being or doing. Patriarchy gives privilege to men, over the centuries of human civilization, to manifest the highest earthly potential. Patriarchy is constructed around an inherent inequality in human relationships. It was encoded first by actions and social structures, and justified in Hellenistic philosophy. In Hellenist philosophy, each person has a "place" in society, namely, the free, citizen and male over slaves, noncitizens and female. Some places are higher than other places, including some placed as slaves to serve others placed as masters. The presumption that a slave is equal to a master in any way was unfathomable, and as such was justification for the institution of slavery. Patriarchy is not just a gender construct. However, in application to gender it mandates a hegemony based on privileging cis men over all others, including women. 


\section{Cosmology in the Qur'an and Islam}

In Islamic cosmology humans descend from a single nafs (soul, self or being). Nafs is feminine grammatically but is used for the essence of the sentient being whether male, female or nonbinary. It has been translated as soul or self; although there are other words for soul in Arabic. Since the word nafs is also used in the Qur'an for the Creator-who is not a being at all-it should not be seen as a substitute for human, except in the way the creation story is told. All of humankind descends from a single nafs according to the explicit Qur'anic pronouncement: "(the Divine) We created you from a single soul (nafsin wahida)" (7:189). The Qur'an does not state that the human sojourn on earth starts with a male person, or even the nafs of a male person. It is taken for granted that the first human was Adam, just as it is taken for granted that Adam was a male person. However, even prior to this human creation the Qur'an assures us: "from all 'things' (the Divine) We have created pairs (min kulli shay'in khalqanaa zawjayn)" (51:49), (Verse 36:36 reads "He created pairs in whatever the earth grows, from themselves and from that which they know not." ${ }^{2}$ ). Thus, male and female are equally essential to this ontological design. Every created thing participates in this binary at some level but not necessarily with hegemony.

Qur'anic cosmology does not include an original sin, which was then assigned as the fault of woman. The language of Qur'anic cosmology uses the unique Arabic dual form and is therefore inclusive. The two ate of the fruit, the two disobeyed Allah, the two sinned (20:120). However, scriptural exegesis at the time of the revelation of the Qur'an often came from Christian and Jewish exegetes of their previous sacred texts. This includes encoding a hegemonic reading of the first human as male, and the first sinner as female. When applied to Qur'anic analysis throughout the centuries, this asymmetrical gendered reading was taken for granted by Muslim scholars and lay persons for centuries. The first time I received a letter threatening my death was after a public lecture in which I debunked the rib story. Someone who admired my analysis wrote an editorial in one of the main newspapers. In response to that editorial, someone left a letter in my Islamic university campus mailbox. It said, if I believed that (there is no rib story), that means I believe something I had not said, which according to the letter writer, was a sign of apostasy, and the punishment for apostasy is death. In other words, the letter writer was interpreting my interpretation of the fact that there is no rib story in the Qur'an. His or her interpretation was then made analogous with apostasy and the punishment of death for apostasy-which is itself an interpretive reading, not agreed upon by all schools of jurisprudence-although here it was stated as if it had complete consensus. The prevailing idea amongst Muslims is that the man (Adam) was put to sleep, and a woman (Eve/Hawaa) was extracted from under his heart. None of these details are in the Qur'anic reading of this story.

This is another example of why it is important to reread the text from a gender perspective. Such a reading challenges certain entrenched ideas and leads to the production of new knowledge. The significance of knowledge production cannot be over stated, especially as related to a religious ethos which includes a revelatory text. Most Muslims expect only to receive religious knowledge that descends from a sacred and unknowable source. In Muslim history, an elite class of interpreters would evolve and eventually be elevated to a level of near infallibility, despite strict rulings against such throughout all of Muslim intellectual history. More vexing is that this elitism denies women's scholarship even when seeking knowledge was incumbent upon women. Women were not denied the right to learn, to think, or to speak except by the imposition of patriarchy in culture. Thus, Muslim majority countries have had lower rates of literacy amongst women than many other countries in the modern world. These limitations cannot be said to be based on the Qur'an or sunnah.

Despite a universal mandate for women to seek knowledge as an integral, even mandatory, part of Islam, women's ways of knowing were not significant in the establishment of the operating paradigms of Islamic thought and praxis. For example, a Hadith of the Prophet says, "seeking knowledge is incumbent upon every Muslim, male and female." Eventually, women's subjective knowledge was deemed incongruent with truth or ortho- 
doxy, while men apparently had no subjectivity and their knowledge was canonized as if sacred or divine. Islamic feminist reforms have returned all interpreters to their status as mere humans struggling to understand and to implement divine mandates.

You cannot imagine how hard it is to disengage men's subjectivities from the copious, often erudite and eloquent constructions of Islamic thought. The moment women seek authority through knowledge production their full humanity can suffer challenges by being chastised as disbelievers, heretics, and even enemies to Islam. Notice how often Muslim women attach the word "believer" or "practicing" to themselves and their intellectual production or activism? To engage in textual analysis from a male perspective is sacrosanct and scholarly; but to engage in textual analysis from a female perspective is heretical, even evil.

Male and female are not closed categories. All that is masculine is not male and all that is feminine is not female. All that is male is not masculine and all that is female is not feminine. Rather feminine and masculine form a spectrum between two points often ascribed as female and male but which are merely binary abstract possibilities. I identify as non-binary because my feminine aspects operate in a constant dynamic relationship with my masculine aspects. Within the spectrum of possibilities, reality is neither exclusive nor absolute. All humans fall along this binary spectrum, with both masculine and feminine attributes, aspects and essences. Gender is a construct. During the foundational discourses of Islamic thought, men dominated the discussion and encoded their own humanity as total and comparable for both women and men. Men became the measure of what it means to be human. The achievement of excellence as a human was often constructed to belong exclusively to men; and yet, even then, not all men.

Men who were servants, travelers, indigent, or not the same ethnicity, color, race, religion and sexual expression were-like all women-also considered deficient in their full humanity. According to Hellenistic philosophy, this was good and just. The differences between the male and the female were presumed to operate within a necessary hegemony with differential treatment and analysis as natural and necessary. If any two beings came together, one must be better than the other. Therefore, men were better. Patriarchy follows the logic of hegemony. In my work, I have advocated a move beyond the flawed logic of hegemony towards a horizontal logic of reciprocity and equality. I will elaborate on this below using the most fundamental principle of Islamic monotheism, tawhid.

Through textual analysis of Qur'anic cosmology from a gender perspective, I constructed a new epistemology of human equality. Starting with the human purpose or teleology, the Qur'an states, "I will make on the earth an agent (Inni ja'ilun fi 'l-'ard Khalifah" [Q 2:30]). A khalifah is a moral agent. There is no original sin that caused a fall to the earth. Earth was always the goal and the place where the human agent fulfills their purpose. As agents on the earth, establishing justice is mandatory. However, as Islamic feminist ethics has unpacked, there were many ways in which agency was given completely to (some) men and only partially to women. Women's agency was best articulated as a completion of men's agency. Otherwise, women were often considered a primary deterrent to men fulfilling their agency.

For example, Zahra Ayubi (2019), in her recent book, Gendered Morality, gives a thorough analysis of how the primary architecture of Muslim philosophy, built upon Hellenistic thought, confirms that men are full moral beings and women-while endowed with a soul-are never able to aspire to completion of the highest moral excellence. In Sa'diyya Shaikh's (2012) book, Sufi Narratives of Intimacy, she elaborates how, even in the mystical traditions of Islam, this hegemony was in operation by discussing a notable exception, Muhyi-din Ibn al-'Arabi, a twelfth century Andalusian philosopher and mystic. He was one of the first Muslim intellectuals to integrate women into discourses about the highest human potential: al-insan al-kamil. While Ibn-al-'Arabi practiced what he preached through a legacy of following women's spiritual teachings as well as behind them in ritual prayer, he also supported some of the standard patriarchal rubrics of his day. 
During the 8th to 13th century Abbasid dynasty, women's voices would be almost totally silenced in Islamic knowledge production. The roles women performed to complete their humanity were not considered agency, especially in jurisprudence. This left a gaping hole rendering people like Ibn al-'Arabi rare exceptions to the rule of male privilege. A few small voices did not change the formulas that were tantamount to sacred mandates. Still today, the active inclusion of women's realities is undervalued in the estimation of the human sojourn from the perspective of (male) Islamic scholars. Recently, Kecia Ali (2013) enumerated the exclusion of women scholars in the citations of almost all Muslim male scholars, even when discussing matters related to women.

When we say women and men are equal, many Muslims takes that to mean women want to be men. Even here, the men are the standard to which women are said to aspire. Another example is when the Sufi hagiographer, Attar, justified the inclusion of the name of the most famous female mystic of Love, Rabi'a al-'Adawiyya (d. 801) in his biography of the saints. He said, "whoever reaches the level of spiritual acumen as Rabi'ah ceases to be a woman. She is counted among the men", implying that the higher a person goes on the scale of spirituality, the more male they become. The measurement of one's humanity, ethics, spirituality and agency are based upon an idealized location for men. Women can never measure up against this because they are their own measurement. The idea that women should be their own measurement has taken some time to be promoted for critical analysis of Islamic sources. As we left the 20th century, scholarship and activism had experienced a radical paradigm shift. Women's agency, creativity, spirituality and scholarship are part of the landscape, even where there are still many places of opposition. Muslim women's voice and agency have reached a critical mass such that we will not be turned back despite efforts to that effect.

I've spent almost 50 years in Qur'anic analysis while never wishing to become a man. I am a woman interested in equality. From my dissertation (Ph.D. University of Michigan, Ann Arbor, MI, USA, Wadud 1988), I projected the idea of reading for: "The Absence of Sex-Role Stereotyping in the Qur'an". A reading that stands in juxtaposition to scholars and activists who give precedent to those Qur'anic statements that repeat the prevailing gender hegemony at the time of revelation as if they are the core of the Qur'an, over statements that participate in equality and reciprocity at the highest level. While hegemony is confirmed as a matter within social and historical contexts, Islamic feminist readings give precedent to statements that affirm the ethics of equality and reciprocity. While Islamic feminist exegesis and activism affirms the personal in their own readings, indicating the ways that male scholars of the past had ignored their personal reading was a strategic political move. The Qur'an is not only prescriptive, it is descriptive. In the Qur'anic world view, the epistemological rhetoric of "othering" is absent. I have addressed all of the hegemonic statements in the Qur'an through my scholarship and activism, but I have not taken them as the standard by which I measure the entire Qur'an. What does it take to establish the Qur'anic construction of gender equality as the central rubric of understanding all of the Qur'an? Then, how do we establish this equality for its ethical implementation? This question aligns Islamic theology with the lived realities of Muslim women.

\section{The Theology of Tawhid as Gender Equality}

I have developed a theological perspective on gender equality over the past two decades. I started with a critical reading of the Introduction chapter in Sachiko Murata's (1992) book, The Tao of Islam. This book accurately depicts the logic of traditional Sufism about complementarity of male/female relationships, including eloquent analogies like sky/earth or pen/tablet. However, these traditional analogues confirm only one active direction, resulting in unequal relationships. The sky lets down to the earth; or the pen writes onto the tablet. Sky and pen are the exclusive active agents, making earth and tablet only receptive. Thus, the male is not like the female.

The graphic depiction shows Allah at the top, male in the middle, female at the bottom. The sky-earth and pen-tablet analogies confirm there is only one active direction: 
down. This depiction presents another problem: there is no direct, unmitigated relationship between Allah at the top and the female at the bottom. The male in the middle interferes with that direct relationship. For while the male receives directly from Allah, and (even) acts directly upon the female, there is a separation between Allah and the female. She cannot receive directly from or interact directly with Allah, because the male is in the way. As a result, the relationship between her and the male is unequal or asymmetrical. The most astounding aspect of the fallacy in this vertical logic-replicated throughout all of normative Islamic cosmology, philosophy and theology from the Classical period-is that it prevents the required direct relation between Allah and each human, no matter the gender, gender expression or gender identity. A direct relationship without intermediary is fundamental in Islamic theology.

The vertical model — while accurately depicting the worldview of Classical thought, culture and practice-could not express the full range of Islamic theology. In reference to Martin Buber's I/Thou and I/It ethical formulas, I re-envisioned Islamic ethics according to a reciprocal model (Buber 1958). The new graphic was like a triangle: Allah was at the top most point putting the male and the female as two points on a horizontal line. Allah is omnipresent, not limited to one fixed point. The coherence of constructing a graphic representation pin points Allah as the highest point but is not meant to capture Allah as if only at that single point. This graphic was necessary to demonstrate the difference between the hegemonic "idealized cosmology" of Classical thought and the tawhidic expression of Islamic feminist thought. The fixed location of Allah in this graphic is a mere metaphorical depiction.

This new model tackled the pervasive patriarchal thinking with men on top, superior to, or in charge of women and non-elite others. I call it the tawhidic paradigm because it is built upon the indisputable and fundamental theological principle of Islam called tawhid. Tawhid means Allah is One, unique. It is derived from the second form of the verb and is thus dynamic: Allah unites. To depict Allah on the top, as the highest metaphysical reality, then places the female and the male on a line of horizontal reciprocity: they must be equal to affirm this oneness of Allah. All who claim to believe in tawhid, and who wish to live in surrender to Allah (another word for "Islam") operate in such a way that the divine reality of One is expressed in all human to human relationship only with reciprocity and equality. This theological construct insists that all forms of social inequity-no matter the basis: sexuality, race, class, religion, ethnicity, geography, etc.- -violates the principle of tawhid which is fundamental in Islam and which grants supremacy only to Allah. Divine unicity demands gender equality.

Despite this tawhidic theological framework, classical Islamic discourse maintained a pervasive, hegemonic, binary logic. In Qur'anic cosmology, the story of Satan provides a clue. Iblis was a jinn, an unseen being created of smokeless fire. Unlike angels, jinns have free will, with which they can choose to surrender to Allah or disobey-like humans. When Iblis was ordered to bow down to the original human person/nafs/soul, he refused, saying, 'I am better than he. He was created from (an atom of) dirt (earth) and I was created from (smokeless) fire.' (Q 38:76) The Arabic word for this is istikbar-to make oneself better than another. This corresponds to the I/It of Martin Buber. In Islamic feminist interpretations of Qur'anic cosmology, inequality results from thinking of oneself as better than another. Furthermore, istikbar is the root of all zulm (systemic oppression: when one group exercises power over others). In the Qur'an, Allah is omnipotent but does not oppress. Oppression, or zulm, is not only inequality but also arrogant and ungodly.

Qur'anic language, syntax and metaphor is absent of the rhetoric of hegemonic juxtaposition on the basis of human to human characteristics and diversity. In the Qur'an, the only qualification of preference is based on the twin rubric of faith and good deeds. The highest ethical term in the Qur'an is taqwa. Taqwa is both the moral consciousness that results from awareness of divine consequence (faith), and ethical actions (deeds) that result from the compassion this consciousness leads to. The Qur'an is explicit, "the most noble of you in the sight of Allah is the one with the most taqwa" (Q 49:13). So, 
while the Qur'an does make note of characteristics or persons placed in situations of elevation over others, these are descriptive passages. The Qur'an is descriptive and prescriptive. Another feature of feminist exegesis is limiting descriptive passages to a particular past while encoding prescriptive passages into their universal benefit across time. Rhetorical hegemony accounts for a manifest I/It social constructs through a satanic consciousness. The statements confirming existing hegemonies are not the substance of Qur'anic prescription.

\section{Lived Reality as Methodology of Legal Reform}

Thus, patriarchy, while pervasive, was merely the faulty logic of a hegemonic binary. The radical reconstruction of Islamic theology and cosmology by Islamic feminist scholarship forms an important part of the solution to dismantle gender inequality by direct reference to Islamic primary sources. However, it is merely the theoretical foundation which insist upon a critical reading of gender. It needs to be in a radical conversation with praxis, as established in activist organizations like Sister in Islam, Malaysia and musawah.org (accessed on 22 June 2021). As the interpretative logic of the tawhidic paradigm mandates equality as built directly from Islam's most sacred texts, it is Islamic in source and construct. It does not merely mimic other feminisms, even when used by Muslims. For while Qur'anic ideals overlap some earlier feminist ideas regarding full human dignity for women, in Islamic feminism, the particulars of an intra-Qur'anic worldview are used over selective or exclusivist models of feminism. Muslims have participated in, added to, and advanced through other forms of feminism even before they were challenged for their lack of intersectionality. Islamic feminism is distinct from earlier Muslim feminisms by its methodology. It cannot be said to belong to all Muslim feminist methodologies. Furthermore, the application of this tawhidic theological paradigm to policy moved the efficacy of Islamic feminism to a new and unprecedented level. This theology could only be derived directly from Islamic primary sources unfettered by centuries of patriarchal hegemonic thinking or by privileging of feminisms from the global north. In the context of the modern nation state, Islamic feminist methodology challenges the habit of justifying certain ideas about women's unequal status and disparate access to full dignity before the law in the name of Islam. Thus, the history of Islamic law comes into consideration.

\section{Shari'ah}

The Islamic legal system starts with a foundational idea called shari'ah, the path that leads to (the source of life) water. It is used as "the way to Allah", "the fulfillment of Divine will", and "the correct path": straight and mandatory. One of the most intense intellectual developments across Muslim time and place was the development of ideas about Shari'ah as a particular Muslim jurisprudence. Eventually, recognized scholars of the law were ascribed unconditional authority—even over matters about which they had no first hand information - because they were almost all male. Dismantling male privilege in Islamic law not only requires a critical reread of gender but also a comprehensive application of that critical reading to the ways in which patriarchal laws are confirmed within the context of modern nation state mechanisms. One important legacy of colonialism was allowing Muslim majority states, or sizable minorities, to determine their own personal status or family law through local customs or religion. Thus, patriarchy became encoded in the law of the land where it remains even until today, despite the other political rubrics of democracy.

The next critical development of Islamic feminism was applying gender inclusive interpretation, along the lines of the tawhidic paradigm, to advocate for reforms in law and policy. This is where context is used to determine the correct application of texts. By highlighting women's lived realities as a key element for the just application of Islamic law, the new interpretive models are linked with the pervasive understanding underlying all disciplines in the Islamic intellectual traditions: that justice is fundamental and universal. 
Islamic feminists asked, if Allah is just, how are unjust laws perpetuated in the name of Allah?

It was difficult to unpack the patriarchal privileging of Islamic law and disentangle it from the state. First, a distinction had to be made between the classical ideal of law, called Shari'ah, and what was actually put into practice, (http://www.zibamirhosseini.com/ documents / mir-hosseini-article-construction-of-gender--2003.pdf, ${ }^{3}$ accessed on 22 June 2021) which is figh. Figh is the human understanding of the right path or Divine Will. Not only is it completely human, it is also context specific. As such, it needs to be continually reconsidered across time and place in order to complete its ultimate mandate: how to justly adhere to a path that leads to Allah. Figh is what has been put into practice at the level of the state, although it is often erroneously called Islamic law and even Shari'ah or the Divine Way. As Abdullah al-Na'im (2008) pointed out, humans can never implement divine law. They can only implement the human estimation of the goals, methods and objectives of the Divine in accordance to the practicality of their interpretation and contexts.

While the primary sources of the Muslim revelatory traditions are used as the knowledge base of Islamic figh, a "crucial feminist contribution to debates in epistemology relates to the relationship between human subjectivity and power relation in the creation of knowledge" according to Sadiyya Shaikh (2013). "Feminist scholars have focused on the often invisible but constitutive relationship between the experiential base of the gendered human subject and the production of knowledge. Using gender as a crucial lens, feminists have examined the forms of religion experience underlying rituals, practices and ethics (in) canonization and authority ... " They developed a "critical inclusive knowledge project..." that "foregrounded the ways that asymmetrical gendered relations of power have" ... "reproduced elite male perspectives on what constitutes religion. This has resulted in ... a biased and static view of religion that has rendered invisible the ways in which women and ordinary men experience and create religion in everyday life."

When knowledge production is stripped of transcendental implications, back to its parts, it is clear that knowledge construction is thoroughly human. Furthermore, if only male humans have been given the authority to determine what is authoritative, then the practice of encoding male privilege and well being runs amok-even to the detriment of female well being. For nearly half a century now, Muslim activists have grappled with the disconnect between a sublime articulation of Islam as a just system honoring the integrity of the individual, and the eclipse of women and nonbinary real lives when looked at in juxtaposition with those articulations. Opposition to the ways personal status or family laws were put into practice was forestalled by both the community and the state by saying these laws are necessary within Islam.

Islamic feminists ask, whose Islam; and how is that Islam constructed? All questions of reform in Islam grapple with these same questions. It was the development of Islamic feminism through the Muslim women's movements however, that brought the most profound challenge to the ways these questions were answered. Put simply. How can there be justice if Muslim women do not experience justice? Throughout the history of Islam, women's subjectivity had never been at the forefront, as it has at the turn of the new millennium. Muslim women do not have to fulfill any criteria or estimations of goodness or practice to warrant the fulfillment of their right to assert what constitutes their integrity. A woman is a khalifah in her own right. Her well being is non-negotiable.

The move from critical textual reinterpretation from an Islamic feminist perspective to policy reform has been one of the most exciting areas of development in the production of new knowledge in Islamic thought. While it is distinguished from earlier Muslim feminisms, it also had a greater impact upon the law and policy. Indeed, Muslim women's advocacy has reached a critical mass. At no time in history has there been this level of collective agency demonstrated by women on behalf of women. Even in the time of radical gender reforms during the Prophet's mission, women were the recipients of reforms, not the architects. There are more Qur'anic passages about the social justice of women than any other aspect of social justice. Yet the trajectory of gender justice in actual societies did not 
keep pace with this sacred beginning. By the time of the Abbasid dynasty, Muslim women's agency had been severely reduced until it had become invisible. This left a gaping hole which Muslim and Islamic feminist agency has begun to fill. What might the future hold?

\section{Way Forward}

In the ongoing reformist discourses about textual analysis, tawhid, and authority, the critical engagement with gender as a category of thought was an important contribution. However, gender was primarily engaged with only as a binary. Today, much needed attention is being given to sexual diversity and nonbinary gender identity. It includes textual interpretations within a newly emerging queer Islamic studies and theology. As another consideration of the way knowledge is being produced, queer Islamic studies provides additional support for the idea of approaching a text with an inclusive ethic of human dignity.

For example, my research on the major passages of the Qur'an about the Prophet Lot/Lut—of his relationship with certain members of his community whose behavior he condemned-confirms that these passages do no provide the definitive conclusions often ascribed to them. The popular idea about the Lot story asserts an interpretation of the Qur'an that says Islam condemns homosexuality. This persistent projection is not borne out after deeper investigation. However, a new analytical consideration proved more beneficial than I expected. What happens when the text alludes to its objection to a certain behavior but does not lead conclusively to how we address that behavior in our current situations? In the Qur'an, the merciful and compassionate God destroys an entire town because of the behavior of some of its members. Even if we agree to this course of action-which gave me pause, I confess-how does God's punishment determine our actions in response to some members of community in our current realities?

First I had to deal with the epistemological and theological crisis of such a contradiction to my notion of Divine mercy and compassion—as is overwhelmingly dominant in the Qur'an. Existing queer theological analysis had already confirmed the methodology of Islamic feminist interpretation by questioning the coherence of the text at all. (For example, Kugle, Scott Siraj al-Haqq. "Sexuality, Diversity and Ethics in the Agenda of Progressive Muslims." In Progressive Muslims, edited by Omid Safi, 190-234. Oxford: Oneworld Publications). ${ }^{4}$ Is it same sex sexual intimacy that is objected to here? No. It was evident that the problematic members of the town were guilty of aggressive sexual assault or rape. They were also described in relation to their inhospitality towards strangers. So, while the tendency to condemn all aspects of gender nonconformity is supposedly derived from these passages, it is not the text that leads to such a conclusion. The text is ambiguous. It also does not tell us what we should do with transgressors. We cannot destroy a whole town because of the behavior of a few, no matter what that behavior might be.

We also cannot derive from the text a clear understanding of the role of other members of the Prophet Lut's own household. The wife of Lut was not saved with the rest of the household although she is not a woman guilty of forced male on male same sex. The daughters of Lut lack agency over their own bodies and are offered in sacrifice to those whose behavior their father had condemned. What does it mean when the Qur'anic discussions leave more questions than answers? It gives an analytical consideration to Qur'anic ambiguity and offers it as a kind of Divine mercy. If we, the people, wish to affirm mercy over assertions of authority or exclusion, we are actually given reign to do so via the Qur'an's failure to outline a more specific course of action by its tendency towards ambiguity - not saying precisely what it might mean.

What if queer Qur'anic analysis is about the liminal spaces created within this ambiguity? How do we negotiate this ambiguity, and to what ethical and spiritual ends? Two aspects of Islamic feminist exegesis become important here. There are major distinctions between the versions of the Lut/Lot stories in the Qur'an and the versions in other Abrahamic scriptures. The practice of classical Qur'anic exegetes of deferring to the exegesis of scholars from earlier Abrahamic texts has not always been helpful. In Islamic feminist anal- 
ysis, these distinctions were pivotal to avoid inheriting problems of patriarchal readings of the Qur'an. It indicates a need to return to the Qur'an as a self sufficient text unencumbered by previous sacred texts and their analysis. This also helped shape inclusive interpretations. This does not close off meaningful exchange and intersectional inter-Abrahamic religious dialogue, but it clarifies how this text must also be read independently to avoid reading more patriarchy into it.

Another important exegetical conclusion was that patriarchal readings lean towards Qatti passages-those that are definitive, explicit, and concrete; providing absolute statements about intent and action. There are also Thanni passages, which are more speculative, implicit, abstract and ambiguous. The overwhelming tendency was to defer to Qatti passages. This made it easier to extrapolate explicit legal postulates from the Qur'an, even when there is a limited capacity for it to act as a legal text. Fewer than 100 verses from more than 6500 have such legal clarity.

Still, because of the powerful push towards developing the fiqh discourse, classical interpretations gave priority to the clear passages. This lent itself towards presuming that all passages are more prescriptive than descriptive. In feminist exegesis, we showed when a patriarchal interpretation was read into a verse from its point of privilege and then this was projected out into law and culture. We also showed how other conclusions could be drawn with a more egalitarian logic by prioritizing more ambiguous passages. In the anthology Men in Charge? (Mir-Hosseini et al. 2015), we confirmed the merits of prioritizing egalitarian statements, whether descriptive or prescriptive, over descriptive hegemonic ones-despite the historical tendency towards the opposite. In other words, when there is a spectrum, which end of the spectrum is emphasized has always been determined by context. Again, context is over text. To defer to verses that lean more towards reciprocity and equality is a matter of simple choice.

Queer Islamic theology, too, has had to grapple with Qur'anic passages often used to promote punitive actions even when not described in the text. Rather, the text is ambiguous about what needs to be done. To embrace the ambiguity is aligned with an ethic of care and human dignity. This ethic of care stems from an expectation that Islam is universal: for all times, all place and all people. Those who say there is no room in Islam for queer Muslims, and then pretend there is a punishment prescribed in the text, are projecting onto a text that gives no concrete recommendation. Furthermore, the punishment in the text is God destroying a whole town. That, in and of itself, is ambiguous. For while we are not God, we are in a relationship with God. The God of the Qur'an introduces Herself with mercy and compassion hundreds of time. Left to our own estimations, we should then likewise prioritize and expect that mercy and compassion. This need to embrace ambiguity leads to greater fluidity thereby allowing more attention to be focused on living contexts as an exegesis of the text. The universality of gender nonconformity becomes the standard against which all projections of ethical behavior are measured.

In addition, this ambiguity helps me in my interest in the Divine Feminine. While Allah has both Jalal, or Sacred Masculine, and Jamal, or Divine Feminine, historically, so much more attention has been given to the masculine that it eclipsed the tawhidic balance with the feminine. I believe the future will reclaim the feminine as a way to enhance the harmony and beauty of the way we will embrace all people as deserving dignity and as a way to indicate our embrace of the Sacred Holy Other as the source of us all. We embrace those who are "othered" amongst us, because somewhere each of us are "othered", and somewhere each of us are aligned with the Divine.

Funding: The research received no external funding.

Institutional Review Board Statement: Not applicable.

Informed Consent Statement: Not applicable.

Data Availability Statement: Not applicable.

Conflicts of Interest: The author declares no conflict of interest. 


\section{Notes}

The Women's Stories, Women's Lives: Male Authority in Muslim Contexts (2016) www.musawah.org, (accessed on 22 June 2021). Verse 36:36 reads "He created pairs in whatever the earth grows, from themselves and from that which they know not."

http:/ / www.zibamirhosseini.com/documents/mir-hosseini-article-construction-of-gender--2003.pdf, (accessed on 22 June 2021). For example, Kugle, Scott Siraj al-Haqq. "Sexuality, Diversity and Ethics in the Agenda of Progressive Muslims." In Progressive Muslims, edited by Omid Safi, 190-234. Oxford: Oneworld Publications.

\section{References}

Ali, Kecia. 2013. The Omnipresent Muslim Male Scholar. In Critical Muslim 08: Men in Islam. Edited by Ziaddin Sardar and Robin Yassin-Kassab. London: Hurst.

al-Na'im, Abdullahi. 2008. Islam and the Secular State. Cambridge: Harvard University Press.

Ayubi, Zahra. 2019. Gendered Morality: Classical Islamic Ethics of the Self, Family and Society. New York: Columbia University Press. Buber, Martin. 1958. I and Thou. New York: Charles Scribner and Sons.

Mir-Hosseini, Ziba, Mulki Shamani, and Jana Rumminger, eds. 2015. Men in Charge? Re-Thinking Authority in Muslim Legal Traditions. London: Oneworld Publications.

Murata, Sachiko. 1992. The Tao of Islam: A Source Book on Gender Relationships in Islamic Thought. Albany: State University of New York Press. Shaikh, Sa'diyya. 2012. Sufi Narratives of Intimacy: Ibn 'Arabi, Gender and Sexuality. Chapel Hill: The University of North Carolina Press. Shaikh, Sa'diyya. 2013. Feminism, Epistemology and Experience: Critically (en) gendering the study of Islam. Journal of Islamic Studies 33: $14-47$.

Wadud, Amina. 1988. Woman in the Qur'an: The Absence of Sex-Role Stereotyping in the Text. Ann Arbor, MI, USA: University of Michigan. Wadud, Amina. 1992. Qur'an and Woman. Kuala Lumpur: Fajar Bakhti Press. 